\title{
Polybenzimidazole and Phosphonic Acid Groups-Functionalized Polyhedral Oligomeric Silsesquioxane Composite Electrolyte for High Temperature Proton Exchange Membrane
}

\author{
Sung-Kon Kim \\ Department of Materials Science and Engineering and Beckman Institute for Advanced Science and Technology, \\ University of Illinois at Urbana-Champaign, Urbana, IL 61801, USA
}

Correspondence should be addressed to Sung-Kon Kim; sk0903@illinois.edu

Received 15 August 2016; Accepted 20 September 2016

Academic Editor: Vincenzo Baglio

Copyright $\odot 2016$ Sung-Kon Kim. This is an open access article distributed under the Creative Commons Attribution License, which permits unrestricted use, distribution, and reproduction in any medium, provided the original work is properly cited.

Here, we report composite membrane consisting of poly[2,2'-(m-phenylene)-5, $5^{\prime}$-(bibenzimidazole)] (PBI) and polyhedral oligomeric silsesquioxane functionalized with phosphonic acid groups $\left(\mathrm{PO}(\mathrm{OH})_{2}\right.$-POSS) for high temperature proton exchange membrane. $\sim 7$ phosphonic acid groups are incorporated into the phenyl rings of POSS via bromination in a high yield ( $\sim 93 \%)$, followed by substitution of the bromine elements by phosphonate ester groups via a $\mathrm{Pd}(0)$ catalyzed $\mathrm{P}-\mathrm{C}$ coupling reaction. Phosphonic acid groups are formed by the hydrolysis of the phosphonate ester groups in hydrobromic acid solution. At a $50 \mathrm{wt} \%$ of PA content in the membranes, $\mathrm{PBI} / \mathrm{PO}(\mathrm{OH})_{2}$-POSS composite membrane shows larger proton conductivity of $3.2 \times 10^{-3} \mathrm{~S} \mathrm{~cm}{ }^{-1}$ than $2.8 \times 10^{-3} \mathrm{~S} \mathrm{~cm}^{-1}$ of PBI membrane at $150^{\circ} \mathrm{C}$ and anhydrous conditions, owing to the multiple phosphonic acid groups of $\mathrm{PO}(\mathrm{OH})_{2}$-POSS that can function as proton transport medium at high temperature and low humidity conditions.

\section{Introduction}

Phosphoric acid (PA)-doped polybenzimidazoles (PBIs) have gained great interests for proton exchange membrane (PEMs) due to their intrinsic attributes such as high proton conductivity (up to $200^{\circ} \mathrm{C}$ ), low gas permeability, excellent oxidative and thermal stabilities, and almost zero water drag coefficient [1-5]. In particular, many attempts on PBI-based organic/inorganic composites have been made to improve the proton conductivity of PEMs that can operate at elevated temperature (generally $100-200^{\circ} \mathrm{C}$ ) and low humidity conditions. Examples of inorganic components include silica $\left(\mathrm{SiO}_{2}\right)[6,7]$, lithium hydrazinium sulfate $\left(\mathrm{LiN}_{2} \mathrm{H}_{5} \mathrm{SO}_{4}\right)$ [8], zirconium phosphates $\left(\mathrm{Zr}\left(\mathrm{HPO}_{4}\right)_{2} \cdot n \mathrm{H}_{2} \mathrm{O}\right)$ [9], zirconium pyrophosphate $\left(\mathrm{ZrP}_{2} \mathrm{O}_{7}\right)$ [10], phosphotungstic acid $\left(\mathrm{H}_{3} \mathrm{PW}_{12} \mathrm{O}_{40} \cdot n \mathrm{H}_{2} \mathrm{O}\right)$ [9], silicotungstic acid $\left(\mathrm{H}_{4} \mathrm{SiW}_{12} \mathrm{O}_{40}\right.$. $\left.n \mathrm{H}_{2} \mathrm{O}\right)$ [9], and boron phosphate $\left(\mathrm{BPO}_{4}\right)$ [11], all of which have led to the improvement of electrochemical and physical properties of PBI electrolytes.

Polyhedral oligomeric silsesquioxane (POSS) has been intensively studied because of its well-defined, three-dimensional nanoscale organic/inorganic hybrid structure that provides interesting opportunities for improving the physical and mechanical properties of polymers due to filler effect $[12,13]$. The development of this compound as a nanobuilding block is important to a variety of applications including electronics, energy, and biomedical engineering [13, 14]. In particular, the properties of POSS can be tuned by incorporating various functionalities such as acrylates, methacrylates, alcohols, amines, carboxylic acids, epoxides, fluoroalkyls, halides, and imides [13, 15-18].

Phosphonic acid groups are attracting much attention because of their high thermal, hydrolytic, and oxidative stabilities [19-22]. They also undergo autodissociation due to intrinsically amphoteric character, leading to the formation of hydrogen bond network [23, 24], and thus can participate in the transport of protons from site to site without carrier molecules via Grotthuss-type mechanism [22, 23, 25]. These distinctive properties are of specific interest to proton conducting electrolytes that operate at high temperature and low humidity conditions. However, it remains a significant challenge to functionalize multiple phosphonic acid groups to molecules (or macromolecular species) due to side reactions such as condensation and aggregation of phosphonic 
acid groups [26, 27]. In this study, the phenyl rings of POSS were functionalized with $\sim 7$ phosphonic acid groups via bromination, followed by phosphonation. The functionalized POSS was incorporated with PBI for use in high temperature PEMs.

\section{Experimental}

2.1. Materials. Bromine $\left(\mathrm{Br}_{2},>99.5 \%\right.$, Aldrich), tetrakis(triphenylphosphine) palladium $(0)\left(\mathrm{Pd}\left(\mathrm{PPh}_{3}\right)_{4}, 99.0 \%\right.$, Aldrich), diethyl phosphate ((EtO) ${ }_{2} \mathrm{POH}, 98.0 \%$, Aldrich), triethylamine (TEA, $\geq 99.0 \%$, TCI), iso-octylphenyl polyhedral oligomeric silsesquioxane (termed as POSS here, Hybrid plastics), hydrobromic acid solution ( $\mathrm{HBr}, 47.0 \sim 49.0 \%$, Daejung), sodium bisulfite ( $\mathrm{NaHSO}_{3}, 58.5 \%$, Daejung), iron (Fe, $>99 \%$, Aldrich), 3,3'-diaminobenzidine (97\%, Tokyo Kasei, TCI), poly(phosphoric acid) (PPA, $116 \% \mathrm{H}_{3} \mathrm{PO}_{4}$, Junsei), phosphorus pentoxide (97\%, Aldrich), and phosphoric acid (PA, $85 \mathrm{wt} \%$ aqueous solution, Aldrich) were used as received. Isophthalic acid (99\%, Aldrich) was purified by recrystallization in ethanol to obtain white needlelike crystals. Solvents were distilled before use.

2.2. Bromination of POSS (Br-POSS). Bromine-substituted POSS (Br-POSS) was synthesized as reported [28]. Briefly, to a $500 \mathrm{~mL}$ round-bottom flask equipped with magnetic stirring bar was added POSS (10.0 g, $9.35 \mathrm{mmol}), \mathrm{Fe}(1.10 \mathrm{~g}$, $19.7 \mathrm{mmol})$, and $100 \mathrm{~mL}$ of $\mathrm{CH}_{2} \mathrm{Cl}_{2} . \mathrm{Br}_{2}(3.61 \mathrm{~mL}, 70.1 \mathrm{mmol})$ was then added portion-wise, and the solution was stirred for $3 \mathrm{~h}$ at room temperature. Subsequently, $100 \mathrm{~mL}$ of $10 \mathrm{wt} \%$ $\mathrm{NaHSO}_{3}$ aqueous solution was added to the solution to remove residual $\mathrm{Br}_{2}$. The solution was then transferred to a separatory funnel to extract the organic layer and then washed three times with distilled water. The solvent was removed by using the rotary evaporator to produce a powder. The resulting powder was dissolved in ethyl acetate and precipitated into $1000 \mathrm{~mL}$ of methanol. The precipitate was obtained through filtering and then dried under vacuum to give a $10.8 \mathrm{~g}$ of final white powder $(93 \%) .{ }^{1} \mathrm{H}$ NMR $(500 \mathrm{MHz}$, DMSO- $\left.d_{6}, \mathrm{ppm}\right): \delta$ 7.95-6.45 (br, $\left.\mathrm{C}_{6} \mathrm{H}_{5}\right), 1.89-0.60(\mathrm{~m}$, $\mathrm{C}_{8} \mathrm{H}_{17}$ ). MALDI-TOF: $m / z=1375.8,1453.7,1534.6,1610.6$, $1688.5,1767.4,1846.3$.

2.3. Synthesis of $\mathrm{PO}(\mathrm{OEt})_{2}$-POSS. A $100 \mathrm{~mL}$ two-neck reactor equipped with nitrogen and condenser was charged with $18 \mathrm{~mL}$ of anhydrous dimethyl sulfoxide (DMSO). Br-POSS $(3.00 \mathrm{~g}, 1.79 \mathrm{mmol})$, diethyl phosphite $(4.59 \mathrm{~mL}, 35.9 \mathrm{mmol})$, and TEA $(5.00 \mathrm{~mL}, 35.9 \mathrm{mmol})$ were added to the reactor, and the mixture was stirred for $10 \mathrm{~min}$; $\mathrm{Pd}\left(\mathrm{PPh}_{3}\right)_{4}(2.07 \mathrm{~g}, 1.79$ $\mathrm{mmol}$ ) was then injected into the reaction flask with high stream of nitrogen and the solution was heated for $72 \mathrm{~h}$ at $100^{\circ} \mathrm{C}$. After cooling to room temperature, the solution was precipitated in distilled water $(1000 \mathrm{~mL})$. The precipitate was then filtered and dried overnight in a vacuum oven to a give brownish powder (86\%). ${ }^{1} \mathrm{H}$ NMR $\left(500 \mathrm{MHz}\right.$, DMSO- $d_{6}$, ppm): $\delta$ 8.36-6.93 (br, $\mathrm{C}_{6} \mathrm{H}_{5}$ ), 3.96-3.31 (br, $\left.\mathrm{CH}_{2}-\mathrm{O}\right), 1.29-$ 0.19 (br, $\mathrm{CH}_{3}$ and $\left.\mathrm{C}_{8} \mathrm{H}_{17}\right)$. ${ }^{31} \mathrm{P}$ NMR $\left(202 \mathrm{MHz}, \mathrm{DMSO}-d_{6}\right.$, ppm): $\delta 26.0$.
2.4. Synthesis of Poly[2,2'-(m-phenylene)-5, $5^{\prime}$-(bibenzimidazole)] (PBI). PPA (90.2 g) was charged into a $250 \mathrm{~mL}$ three-neck reactor equipped with a mechanical stirrer, nitrogen inlet, and calcium chloride drying tube and heated for $30 \mathrm{~min}$ at $150^{\circ} \mathrm{C}$. DABI $(2.78 \mathrm{~g}, 13.0 \mathrm{mmol})$ and IPA $(2.16 \mathrm{~g}$, $13.0 \mathrm{mmol}$ ) were then added gradually, and the solution was stirred for $1 \mathrm{~h}$ at $150^{\circ} \mathrm{C}$ under a slow nitrogen stream and mechanical stirring until it became a homogeneous solution. The reaction temperature was raised to $200^{\circ} \mathrm{C}$. After $30 \mathrm{~min}$, phosphorus pentoxide $(4.84 \mathrm{~g}, 17.0 \mathrm{mmol})$ was added and the reaction continued for $12 \mathrm{~h}$ at $200^{\circ} \mathrm{C}$ with constant stirring using a mechanical stirrer to obtain a very viscous dark brown solution. The reaction mixture was isolated into the polymer in distilled water $(1000 \mathrm{~mL})$ and the precipitate was then neutralized with an aqueous solution of $\mathrm{NaHCO}_{3}$ and rinsed several times with distilled water to remove phosphate salts. It was dried overnight under vacuum. The resulting polymer was ground using a pulverizer (All basic, IKA) and washed again to remove any residual phosphoric acid. Finally, the powder was dried at $70^{\circ} \mathrm{C}$ in a vacuum oven for at least 3 days $(>95 \%)$. ${ }^{1} \mathrm{H}$ NMR $\left(500 \mathrm{MHz}\right.$, DMSO- $\left.d_{6}, \mathrm{ppm}\right)$ : $\delta 9.14(\mathrm{~s}, 1 \mathrm{H}), 8.32(\mathrm{~d}, 2 \mathrm{H}), 8.00(\mathrm{~s}, 2 \mathrm{H}), 7.81(\mathrm{~d}, 2 \mathrm{H}), 7.62$ (br, $3 \mathrm{H})$.

2.5. Preparation of Composite Membranes. $4.0 \mathrm{~g}$ of PBI powder and $1.0 \mathrm{~g}$ of $\mathrm{PO}(\mathrm{OEt})_{2}$-POSS were dissolved in a $166 \mathrm{~g}$ of $\mathrm{N}, \mathrm{N}$-dimethylacetamide (DMAc) at $80^{\circ} \mathrm{C}$. The mixed solution was then spread onto a clean flat glass plate. The thickness of the solution was controlled using an adjustable doctor blade, and the casted solution was left to dry at $80^{\circ} \mathrm{C}$ for $12 \mathrm{~h}$ until no DMAc evaporation was noted. After cooling to room temperature, the obtained film was soaked in distilled water and peeled off the substrate. The resulting film was dried using gel dryer at $60^{\circ} \mathrm{C}$ for $1 \mathrm{~h}$, and then the film was further dried under vacuum for $12 \mathrm{~h}$. To convert POSS in phosphonated ester form ( $\mathrm{PO}(\mathrm{OEt})_{2}$-POSS $)$ into that in phosphonic acid form $\left(\mathrm{PO}(\mathrm{OH})_{2}\right.$-POSS), the composite membranes containing $\mathrm{PO}(\mathrm{OEt})_{2}$-POSS were soaked in concentrated $\mathrm{HBr}$ solution at reflux for $24 \mathrm{~h}$. The composite films were thoroughly washed with distilled water several times to neutralize and to remove excess acid and then dried using gel dryer at $60^{\circ} \mathrm{C}$ for $1 \mathrm{~h}$, and then the film was further dried in a vacuum oven for $12 \mathrm{~h}$. The $\mathrm{PBI}$ and $\mathrm{PO}\left(\mathrm{OH}_{2}\right)$-POSS composite film obtained was weighed $\left(W_{1}\right)$ and immersed in $1000 \mathrm{~mL}$ of the PA solution with $60 \mathrm{wt} \%$ concentration at $80^{\circ} \mathrm{C}$ for $4 \mathrm{~h}$. The PA-doped membrane was taken out of the PA solution and then blotted with filter paper. The membrane was dried at $70^{\circ} \mathrm{C}$ under vacuum for 2 days and weighed again $\left(W_{2}\right)$. The weight difference, $\left(W_{2}-W_{1}\right)$, was assumed to be the weight of the absorbed PA. The PA content of the membrane was then calculated as the weight percent ( $w \mathrm{t} \%$ ) of PA absorbed in the membrane using

$$
\text { PA content }(\mathrm{wt} \%)=\frac{\left(W_{2}-W_{1}\right)}{W_{2}} \times 100 .
$$

2.6. Characterization. Matrix-assisted laser desorption/ionization time-of-flight mass spectroscopy (MALDI-TOF/MS) 
was recorded on a Voyager-DE ${ }^{\mathrm{TM}}$ STR Biospectrometry Workstation (Applied Biosystems Inc.) set in the positive reflection mode using dithranol as the matrix. The MALDITOF/MS instrument was equipped with a nitrogen laser which was emitting at $337 \mathrm{~nm}$ with a $3 \mathrm{~ns}$ pulse width. The ${ }^{1} \mathrm{H}$ and ${ }^{31} \mathrm{P}$ nuclear magnetic resonance (NMR) spectra were collected on Bruker Avance 500 with a proton frequency of $500 \mathrm{MHz}$. During the experiments, deuterated dimethyl sulfoxide was used as the solvent and tetramethylsilane (TMS) was used as the internal standard. Fourier transform infrared (FT-IR) spectra of dried membranes and powder samples were recorded in the attenuated total reflectance (ATR) mode in the frequency range of $4000 \sim 650 \mathrm{~cm}^{-1}$ on a Nicolet 6700 instrument (Thermo Scientific, USA). The spectrum was recorded as the average of 32 scans with the resolution of $8 \mathrm{~cm}^{-1}$. Each of the samples was put in equal physical contact with the sampling plate of the spectrometer accessory to avoid differences caused by pressure and penetration depth. The chemical composition and concentration of the material were determined by field-emission scanning electron microscopy (FE-SEM, Carl Zeiss SUPRA 55VP), operated at an accelerating voltage of $15 \mathrm{kV}$ and equipped with energydispersive spectroscopy (EDS) capabilities. Proton conductivity was measured using a four-point probe. Impedance was measured using a ZAHNER IM-6ex impedance analyzer in potentiostat mode with a perturbation amplitude of $10 \mathrm{mV}$ over frequencies of $1 \mathrm{~Hz}$ to $1 \mathrm{MHz}$. Impedance at a controlled humidity and temperature was measured from Nyquist plots. Proton conductivity $(\sigma)$ was calculated using $\sigma=d / R S$, where $d$ is the distance between the reference and sensing electrodes and $S$ is the cross-sectional area (thickness $x$ width) of the doped membrane. $1 \mathrm{~cm} \times 5 \mathrm{~cm}$ membranes were introduced to the conductivity cell and heated to $160^{\circ} \mathrm{C}$ and held for $30 \mathrm{~min}$. Measurements were taken as the cell then cooled to $100^{\circ} \mathrm{C}$ in $10^{\circ} \mathrm{C}$ steps.

\section{Results and Discussion}

Iso-octylphenyl polyhedral oligomeric silsesquioxane, which we term POSS here, was brominated by a coupling reaction in high yield (ca. 93\%) as reported (abbreviated as $\mathrm{Br}$ POSS, Figure 1) $[28,29]$ and characterized by using MALDITOF/MS, ${ }^{1} \mathrm{H}$ NMR and ATR FT-IR. MALDI-TOF/MS of BrPOSS shows a series of peaks separated by $79 \mathrm{amu}$ of bromine, centered at $1610 \mathrm{~m} / z$ (Figure 2). It indicates that an average of $\sim 7$ bromine elements per POSS was incorporated. This observation was further supported by ${ }^{1} \mathrm{H}$ NMR spectra (Figure 3). The bromination of POSS results in the broadening of proton peaks associated with the phenyl rings of POSS $(\delta=8.1 \sim 6.3 \mathrm{ppm})$, while the peaks of isooctyl moiety $(\delta$ $<2.0 \mathrm{ppm}$ ) remain unchanged, demonstrating that bromine elements are incorporated into the phenyl rings of POSS. The extent of bromine elements incorporated was calculated by the comparison of integrals of proton peaks associated with the phenyl ring and the isooctyl moieties. The average number of the bromine elements per POSS determined by
${ }^{1} \mathrm{H}$ NMR spectra was $\sim 7.6$, close to MALDI-TOF/MSdetermined value. Figure 4 shows ATR FT-IR spectra of BrPOSS. The characteristic absorption band assigned to stretching vibration for aromatic halogen compound appears at $1009 \mathrm{~cm}^{-1}$. The bands at 894,810 , and $784 \mathrm{~cm}^{-1}$ are also ascribed to bromine-incorporated phenyl rings of POSS.

The bromine elements of Br-POSS were substituted with phosphonate ester groups via a $\mathrm{Pd}(0)$ catalyzed $\mathrm{P}-\mathrm{C}$ coupling reaction, which was carried out with diethyl phosphite $\left((\mathrm{EtO})_{2} \mathrm{POH}\right)$ and tetrakis(triphenylphosphine) palla$\operatorname{dium}(0)\left(\mathrm{Pd}\left(\mathrm{PPh}_{3}\right)_{4}\right)$ as a catalyst with trimethylamine (TEA) $[26,30,31]$; the resulting compound is named $\mathrm{PO}(\mathrm{OEt})_{2}$ POSS (Figure 1). We observed the peaks of the $\mathrm{CH}_{2}$ and $\mathrm{CH}_{3}$ protons of phosphonate ester groups at $\delta=3.80$ and 1.15 ppm, respectively, in ${ }^{1} \mathrm{H}$ NMR spectra, as a consequence of substitution of phosphonate esters for bromine elements (Figure 3) [31]. Figure 5 presents ${ }^{31} \mathrm{P}$ NMR spectra of $\mathrm{PO}(\mathrm{OEt})_{2}$-POSS and diethyl phosphite, a monomer used for the substitution reaction. The phosphorous signal associated with phosphonate ester units of $\mathrm{PO}\left(\mathrm{OEt}_{2}\right)$-POSS is shifted downfield by $\sim 17 \mathrm{ppm}$ as compared to that of diethyl phosphite because of the substitution reaction. ATR FT-IR spectra also provide the information regarding the substitution reaction (Figure 4$)$. The phosphoryl linkage $(\mathrm{P}=\mathrm{O})$ stretching appears at around $1680 \mathrm{~cm}^{-1}$. The bands at 1048 and $1023 \mathrm{~cm}^{-1}$ are assigned to $\mathrm{P}-\mathrm{O}-\mathrm{C}$ absorptions of the ester group, and the band at $949 \mathrm{~cm}^{-1}$ is attributed to $\mathrm{P}-\mathrm{O}-\mathrm{C}$ vibrations [27, 31]. SEM/EDS measurement was conducted to verify substitution from bromine elements to phosphonate ester groups (Figure 6). No notable peaks of bromine elements are observed. A single peak of phosphorus appears at $\sim 2.1 \mathrm{keV}$ and its intensity is comparable with that of silicon at $\sim 1.9 \mathrm{keV}$. Assuming that the substitution occurred completely, the number of phosphorous elements per POSS should be $\sim 7$, which is the same with that of silicon of POSS. Accordingly, the atomic weight ratio of phosphorus to silicon for $\mathrm{PO}(\mathrm{OEt})_{2}$-POSS determined through EDS is unity, supporting the assumption that bromine elements were completely substituted by phosphonate ester groups.

Following the protocol we and others have explored, poly $\left[2,2^{\prime}\right.$-( $m$-phenylene) $-5,5^{\prime}$-(bibenzimidazole) $]$ (PBI) was synthesized by a condensation polymerization and fabricated into a freestanding membrane through a solution casting method commonly used, which was also applied to the fabrication of $\mathrm{PBI} / \mathrm{PO}(\mathrm{OEt})_{2}$-POSS composite membrane. The phosphonate ester units of $\mathrm{PO}(\mathrm{OEt})_{2}$-POSS were readily converted into the phosphonic acid ones, denoted as $\mathrm{PO}(\mathrm{OH})_{2}$-POSS, by hydrolysis in hydrobromic acid $(\mathrm{HBr})$ solution as demonstrated in Figure 1. In addition, in ATR FTIR spectra, the characteristic bands associated with phosphonate ester groups of $\mathrm{PO}(\mathrm{OEt})_{2}$-POSS disappear, implying the substitution of phosphonic acids for phosphonate esters (Figure 4). More importantly, $\mathrm{PO}(\mathrm{OEt})_{2}$-POSS is soluble in organic solvents such as DMSO and DMAc while its solubility decreases significantly, once the hydrolysis is performed, which is most likely due to strong hydrogen bond network formed between phosphonic acid groups [31, 32]. Due to such dissolution issue of $\mathrm{PO}(\mathrm{OH})_{2}$-POSS in organic solvents, 


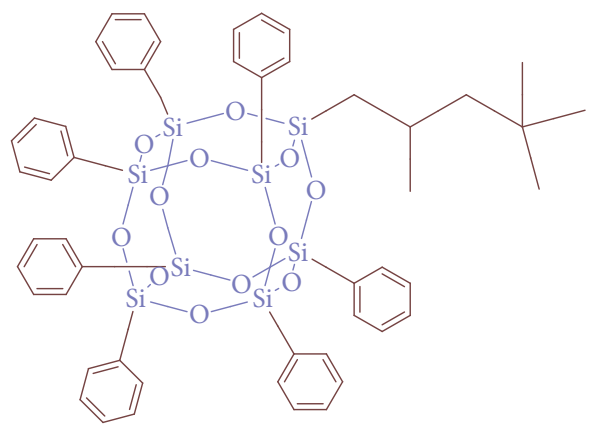

POSS

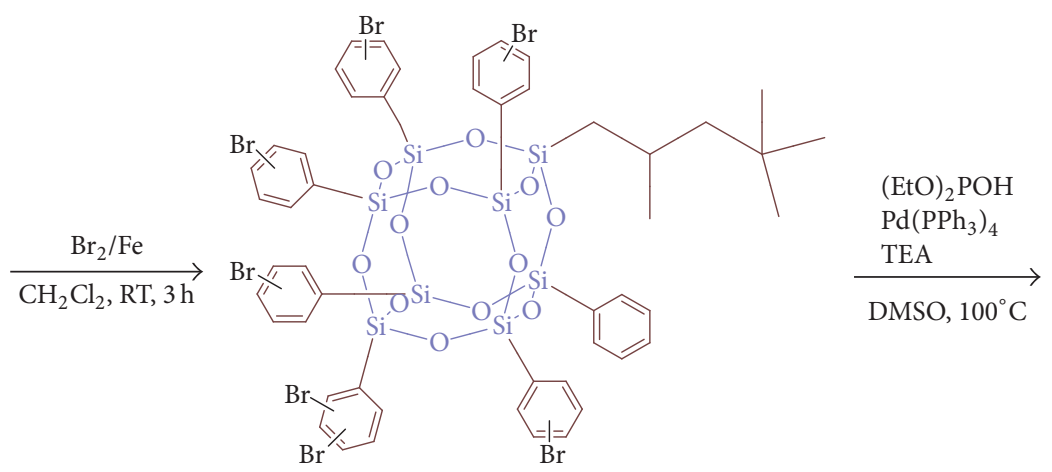

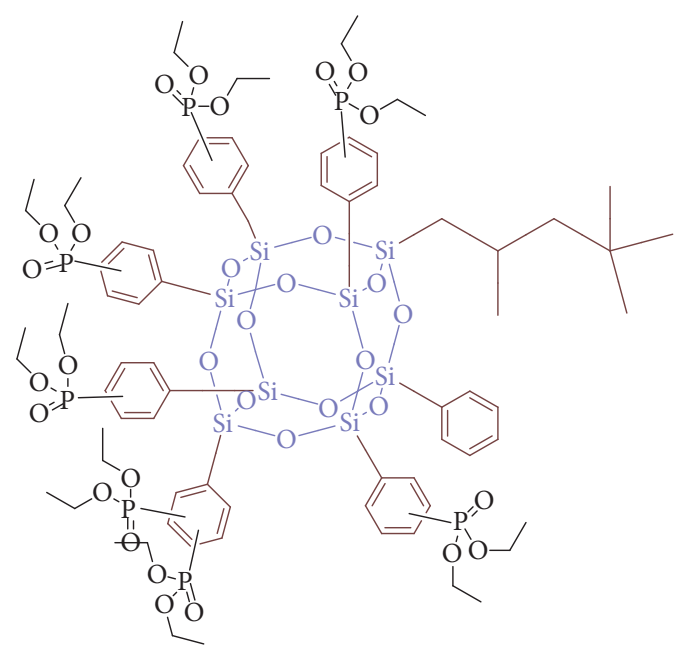

$\mathrm{PO}(\mathrm{OEt})_{2}$-POSS

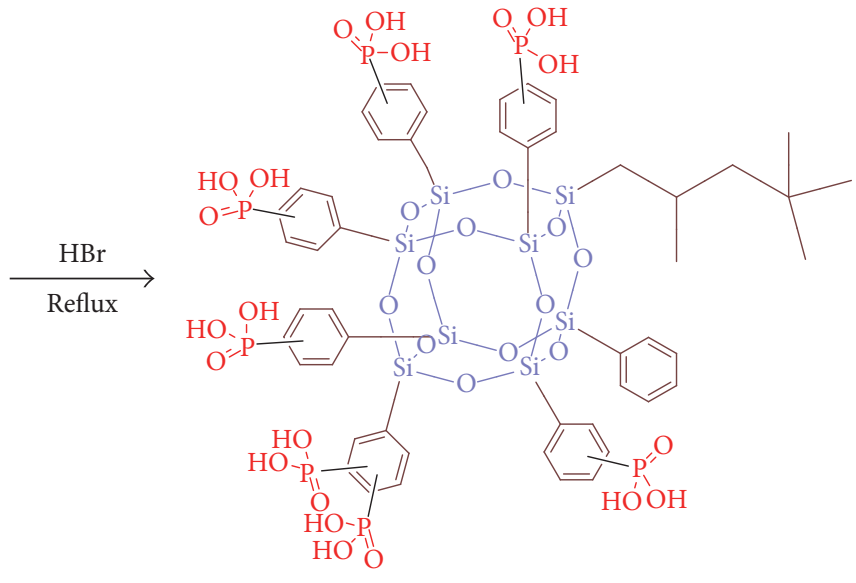

$\mathrm{PO}(\mathrm{OH})_{2}$-POSS

FIGURE 1: Synthesis of phosphonic acids-functionalized POSS.

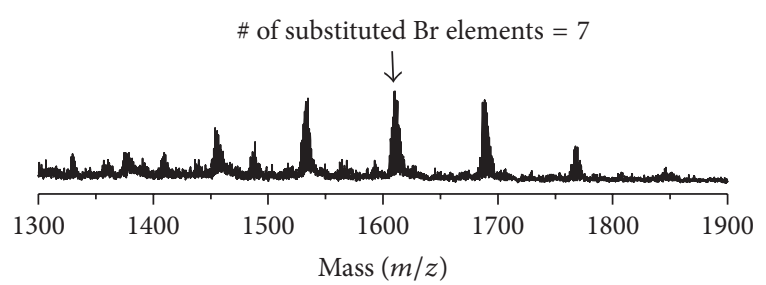

Figure 2: MALDI-TOF/MS of Br-POSS.

$\mathrm{PO}(\mathrm{OEt})_{2}$-POSS, which is soluble in DMAc, was mixed with PBI for freestanding film formation prior to hydrolysis. The doping of the composite membrane in $60 \mathrm{wt} \%$ PA solution imparts proton conducting capability of the membrane. The PA content absorbed in the membranes is $\sim 50 \mathrm{wt} \%$.

Figure 7 shows the proton conductivities of the PA-doped membranes with temperature ranging from 100 to $150^{\circ} \mathrm{C}$ under anhydrous conditions. Not surprisingly, the proton conductivity increases with increasing temperature, an observation common to all studies on PA-doped PBI derivative membranes [5, 25, 33-36]. In particular, $\mathrm{PBI} / \mathrm{PO}(\mathrm{OH})_{2}$-POSS composite membrane provides greater proton conductivity, $3.2 \times 10^{-3} \mathrm{~S} \mathrm{~cm}^{-1}$, than PBI membrane $\left(2.8 \times 10^{-3} \mathrm{~S} \mathrm{~cm}^{-1}\right)$ at

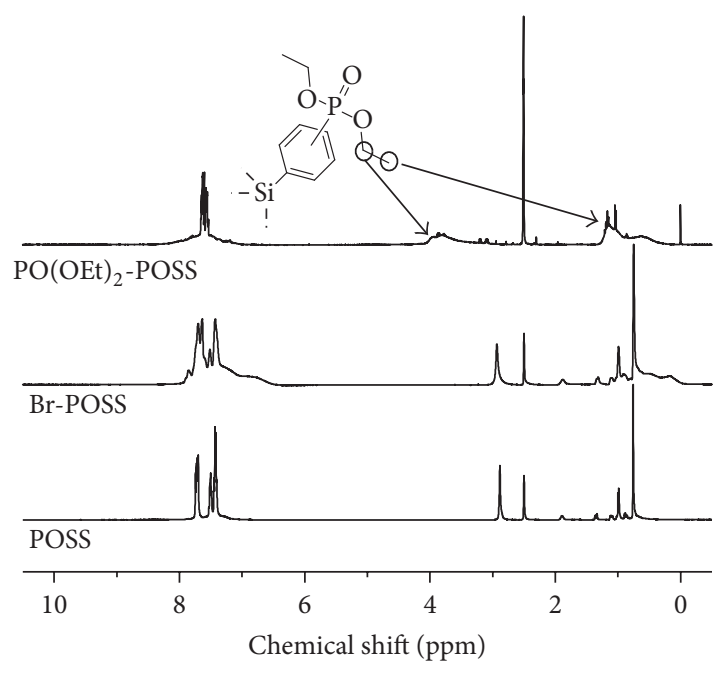

Figure $3:{ }^{1} \mathrm{H}$ NMR spectra of POSS, Br-POSS, and PO(OEt $)_{2}$-POSS.

a given temperature. The conductivity against temperature exhibits the Arrhenius behavior $\left(\sigma=\sigma_{0} \exp \left(-E_{a} / R T\right)\right.$, where $\sigma_{0}$ is the preexponential factor and $E_{a}$ is the activation energy 


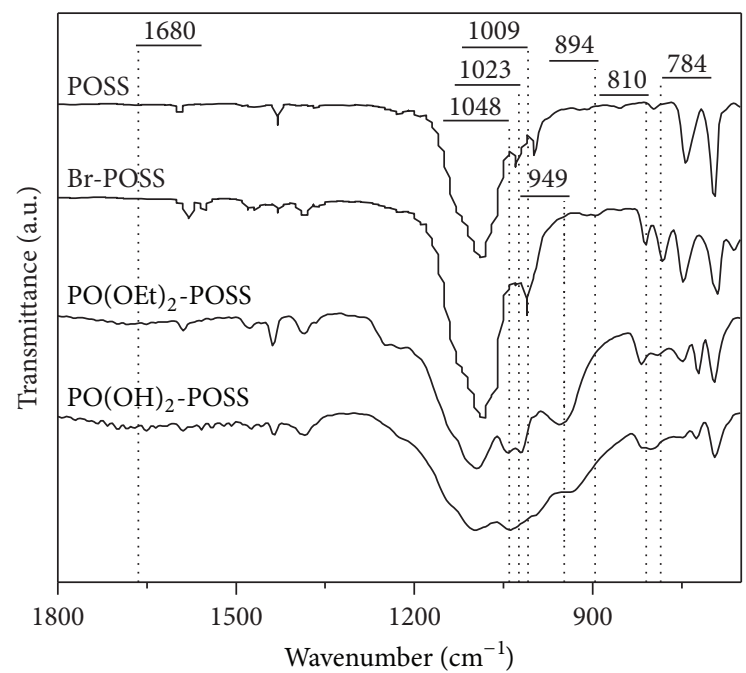

Figure 4: ATR FT-IR spectra of POSS, Br-POSS, PO(OEt) $)_{2}$-POSS, and $\mathrm{PO}(\mathrm{OH})_{2}$-POSS.

Diethyl phosphite

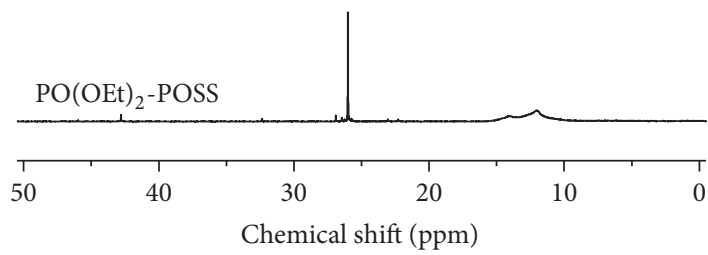

FIGURE 5: ${ }^{31} \mathrm{P}$ NMR spectra of diethyl phosphite and $\mathrm{PO}(\mathrm{OEt})_{2}{ }^{-}$ POSS.

for the proton conduction), indicating that proton conduction in the membrane follows a proton-hopping dominant mechanism (Grotthuss-type mechanism) as reported by other reports $[33,34,37]$. We thus speculate that $\sim 7$ phosphonic acid groups of $\mathrm{PO}(\mathrm{OH})_{2}$-POSS provide a better pathway for proton conduction as they bridge the apparent gap between PAs (and/or PA and PBI) via the hopping mechanism.

\section{Conclusions}

In summary, we succeeded in functionalizing POSS with $\sim 7$ phosphonic acid groups. Following bromination, $\sim 7$ bromine elements of POSS were substituted with phosphonate ester groups, which were further hydrolyzed into phosphonic acid groups in hydrobromic acid solution. The solubility of the POSS significantly decreased after the hydrolysis, which might be due to hydrogen bond network formed between phosphonic acids. The functionalized $\mathrm{PO}(\mathrm{OH})_{2}$-POSS was hybridized with PBI and the composite was fabricated into freestanding membrane, followed by doping in PA solution.

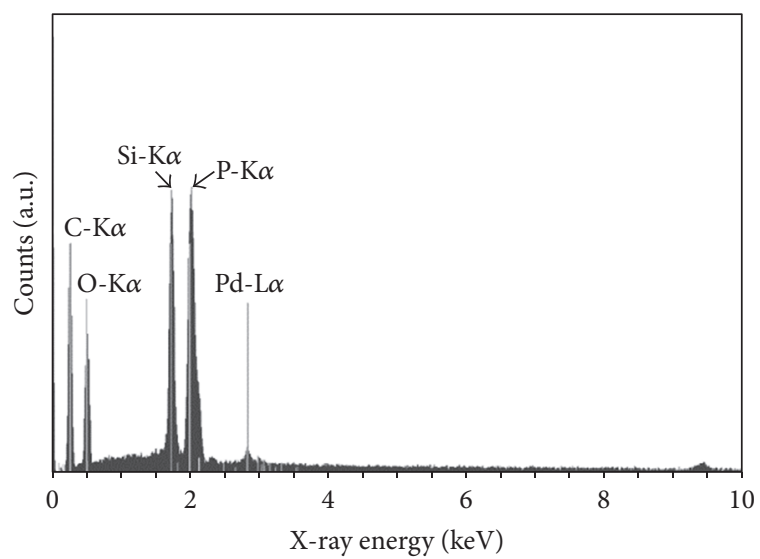

FIGURE 6: SEM/EDS spectroscopy of $\mathrm{PO}(\mathrm{OEt})_{2}$-POSS.

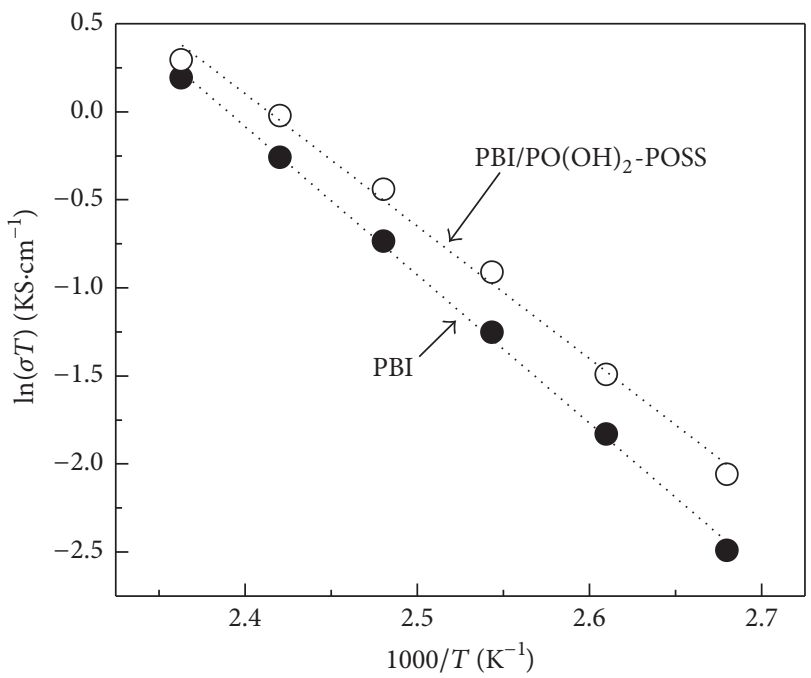

Figure 7: Proton conductivities of PA-doped PBI and PBI/ $\mathrm{PO}(\mathrm{OH})_{2}$-POSS membranes with temperature ranging from 100 to $150^{\circ} \mathrm{C}$ under anhydrous conditions. PA content of the membranes is ca. $50 \mathrm{wt} \%$.

The PA-doped composite membrane retains proton conductivity greater than that of PBI membrane at high temperature over $100^{\circ} \mathrm{C}$ and low humidity conditions. We conclude that phosphonic acids-functionalized POSS as a filler provides considerable increase in proton conducting capability of polymer electrolyte operating at high temperature.

\section{Competing Interests}

The author declares that there are no competing interests regarding the publication of this paper.

\section{References}

[1] J. S. Wainright, J.-T. Wang, D. Weng, R. F. Savinell, and M. Litt, "Acid-doped polybenzimidazoles: a new polymer electrolyte," Journal of the Electrochemical Society, vol. 142, no. 7, pp. L121L123, 1995. 
[2] J. Weber, K.-D. Kreuer, J. Maier, and A. Thomas, "Proton conductivity enhancement by nanostructural control of poly(benzimidazole)-phosphoric acid adducts," Advanced Materials, vol. 20, no. 13, pp. 2595-2598, 2008.

[3] Q. Li, R. He, J. O. Jensen, and N. J. Bjerrum, "PBI-based polymer membranes for high temperature fuel cells-preparation, characterization and fuel cell demonstration," Fuel Cells, vol. 4, no. 3, pp. 147-159, 2004.

[4] L. Xiao, H. Zhang, E. Scanlon et al., "High-temperature polybenzimidazole fuel cell membranes via a sol-gel process," Chemistry of Materials, vol. 17, no. 21, pp. 5328-5333, 2005.

[5] S.-K. Kim, T.-H. Kim, J.-W. Jung, and J.-C. Lee, "Polybenzimidazole containing benzimidazole side groups for hightemperature fuel cell applications," Polymer, vol. 50, no. 15, pp. 3495-3502, 2009.

[6] E. Quartarone, P. Mustarelli, A. Carollo, S. Grandi, A. Magistris, and C. Gerbaldi, "PBI composite and nanocomposite membranes for PEMFCs: the role of the filler," Fuel Cells, vol. 9, no. 3, pp. 231-236, 2009.

[7] P. Mustarelli, A. Carollo, S. Grandi et al., "Composite protonconducting membranes for PEMFCs," Fuel Cells, vol. 7, no. 6, pp. 441-446, 2007.

[8] J.-W. Jung, S.-K. Kim, and J.-C. Lee, "Preparation of polybenzimidazole/lithium hydrazinium sulfate composite membranes for high-temperature fuel cell applications," Macromolecular Chemistry and Physics, vol. 211, no. 12, pp. 1322-1329, 2010.

[9] R. He, Q. Li, G. Xiao, and N. J. Bjerrum, "Proton conductivity of phosphoric acid doped polybenzimidazole and its composites with inorganic proton conductors," Journal of Membrane Science, vol. 226, no. 1-2, pp. 169-184, 2003.

[10] T.-H. Kim, T.-W. Lim, Y.-S. Park, K. Shin, and J.-C. Lee, "Protonconducting zirconium pyrophosphate/poly(2,5-benzimidazole) composite membranes prepared by a PPA direct casting method," Macromolecular Chemistry and Physics, vol. 208, no. 21, pp. 2293-2302, 2007.

[11] S. M. J. Zaidi, "Preparation and characterization of composite membranes using blends of SPEEK/PBI with boron phosphate," Electrochimica Acta, vol. 50, no. 24, pp. 4771-4777, 2005.

[12] S.-W. Kuo and F.-C. Chang, "POSS related polymer nanocomposites," Progress in Polymer Science, vol. 36, no. 12, pp. 16491696, 2011.

[13] D. B. Cordes, P. D. Lickiss, and F. Rataboul, "Recent developments in the chemistry of cubic polyhedral oligosilsesquioxanes," Chemical Reviews, vol. 110, no. 4, pp. 2081-2173, 2010.

[14] D.-G. Kim, J. Shim, J. H. Lee, S.-J. Kwon, J.-H. Baik, and J.-C. Lee, "Preparation of solid-state composite electrolytes based on organic/inorganic hybrid star-shaped polymer and PEG-functionalized POSS for all-solid-state lithium battery applications," Polymer, vol. 54, no. 21, pp. 5812-5820, 2013.

[15] K. J. Shea and D. A. Loy, "Bridged polysilsesquioxanes. Molecular-engineered hybrid organic-inorganic materials," Chemistry of Materials, vol. 13, no. 10, pp. 3306-3319, 2001.

[16] J. D. Lichtenhan, Y. A. Otonari, and M. J. Carr, "Linear hybrid polymer building blocks: methacrylate-functionalized polyhedral oligomeric silsesquioxane monomers and polymers," Macromolecules, vol. 28, no. 24, pp. 8435-8437, 1995.

[17] M. Takeda, K. Kuroiwa, M. Mitsuishi, and J. Matsui, "Selfassembly of amphiphilic POSS anchoring a short organic tail with uniform structure," Chemistry Letters, vol. 44, no. 11, pp. 1560-1562, 2015.
[18] S.-Y. Kuwahara, K. Yamamoto, and J.-I. Kadokawa, "Synthesis of amphiphilic polyhedral oligomeric silsesquioxane having a hydrophobic fluorescent dye group and its formation of fluorescent nanoparticles in water," Chemistry Letters, vol. 39, no. 10, pp. 1045-1047, 2010.

[19] D. D. Jiang, Q. Yao, M. A. McKinney, and C. A. Wilkie, “TGA/ FTIR studies on the thermal degradation of some polymeric sulfonic and phosphonic acids and their sodium salts," Polymer Degradation and Stability, vol. 63, no. 3, pp. 423-434, 1999.

[20] M. Schuster, T. Rager, A. Noda, K. D. Kreuer, and J. Maier, "About the choice of the protogenic group in PEM separator materials for intermediate temperature, low humidity operation: a critical comparison of sulfonic acid, phosphonic acid and imidazole functionalized model compounds," Fuel Cells, vol. 5, no. 3, pp. 355-365, 2005.

[21] A. Kaltbeitzel, S. Schauff, H. Steininger et al., "Water sorption of poly(vinylphosphonic acid) and its influence on proton conductivity," Solid State Ionics, vol. 178, no. 7-10, pp. 469-474, 2007.

[22] B. Lafitte and P. Jannasch, "Polysulfone ionomers functionalized with benzoyl(difluoromethylenephosphonic acid) side chains for proton-conducting fuel-cell membranes," Journal of Polymer Science, Part A: Polymer Chemistry, vol. 45, no. 2, pp. 269-283, 2007.

[23] R. Tayouo, G. David, B. Améduri, J. Rozière, and S. Roualdès, "New fluorinated polymers bearing pendant phosphonic acid groups. Proton conducting membranes for fuel cell," Macromolecules, vol. 43, no. 12, pp. 5269-5276, 2010.

[24] E. Labalme, G. David, P. Buvat, J. Bigarre, and T. Boucheteau, "New hybrid membranes based on phosphonic acid functionalized silica particles for PEMFC," Journal of Polymer Science Part A: Polymer Chemistry, vol. 50, no. 7, pp. 1308-1316, 2012.

[25] S.-K. Kim, S.-W. Choi, W. S. Jeon et al., "Cross-linked benzoxazine-benzimidazole copolymer electrolyte membranes for fuel cells at elevated temperature," Macromolecules, vol. 45, no. 3, pp. 1438-1446, 2012.

[26] K. Jakoby, K. V. Peinemann, and S. P. Nunes, "Palladiumcatalyzed phosphonation of polyphenylsulfone," Macromolecular Chemistry and Physics, vol. 204, no. 1, pp. 61-67, 2003.

[27] B. Lafitte and P. Jannasch, "Phosphonation of polysulfones via lithiation and reaction with chlorophosphonic acid esters," Journal of Polymer Science, Part A: Polymer Chemistry, vol. 43, no. 2, pp. 273-286, 2005.

[28] M. D. Guiver, O. Kutowy, and J. W. ApSimon, "Functional group polysulphones by bromination-metalation," Polymer, vol. 30, no. 6, pp. 1137-1142, 1989.

[29] C. M. Brick, R. Tamaki, S.-G. Kim et al., "Spherical, polyfunctional molecules using poly(bromophenylsilsesquioxane)s as nanoconstruction sites," Macromolecules, vol. 38, no. 11, pp. 4655-4660, 2005.

[30] M. Kalek and J. Stawinski, "Pd(0)-catalyzed phosphoruscarbon bond formation. Mechanistic and synthetic studies on the role of the palladium sources and anionic additives," Organometallics, vol. 26, no. 24, pp. 5840-5847, 2007.

[31] K. Miyatake and A. S. Hay, "New poly(arylene ether)s with pendant phosphonic acid groups," Journal of Polymer Science, Part A: Polymer Chemistry, vol. 39, no. 21, pp. 3770-3779, 2001.

[32] J. Parvole and P. Jannasch, "Polysulfones grafted with poly(vinylphosphonic acid) for highly proton conducting fuel cell membranes in the hydrated and nominally dry state," Macromolecules, vol. 41, no. 11, pp. 3893-3903, 2008. 
[33] R. Bouchet and E. Siebert, "Proton conduction in acid doped polybenzimidazole," Solid State Ionics, vol. 118, no. 3-4, pp. 287299, 1999.

[34] A. Bozkurt, W. H. Meyer, and G. Wegner, "PAA/imidazolbased proton conducting polymer electrolytes," Journal of Power Sources, vol. 123, no. 2, pp. 126-131, 2003.

[35] S.-K. Kim, T. Ko, S.-W. Choi et al., "Durable cross-linked copolymer membranes based on poly(benzoxazine) and poly $(2,5-$ benzimidazole) for use in fuel cells at elevated temperatures," Journal of Materials Chemistry, vol. 22, no. 15, pp. 7194-7205, 2012.

[36] S.-K. Kim, K.-H. Kim, J. O. Park et al., "Highly durable polymer electrolyte membranes at elevated temperature: crosslinked copolymer structure consisting of poly(benzoxazine) and poly(benzimidazole)," Journal of Power Sources, vol. 226, pp. 346-353, 2013.

[37] H.-S. Lee, A. Roy, O. Lane, and J. E. McGrath, "Synthesis and characterization of poly(arylene ether sulfone)-b-polybenzimidazole copolymers for high temperature low humidity proton exchange membrane fuel cells," Polymer, vol. 49, no. 25, pp. 5387-5396, 2008. 

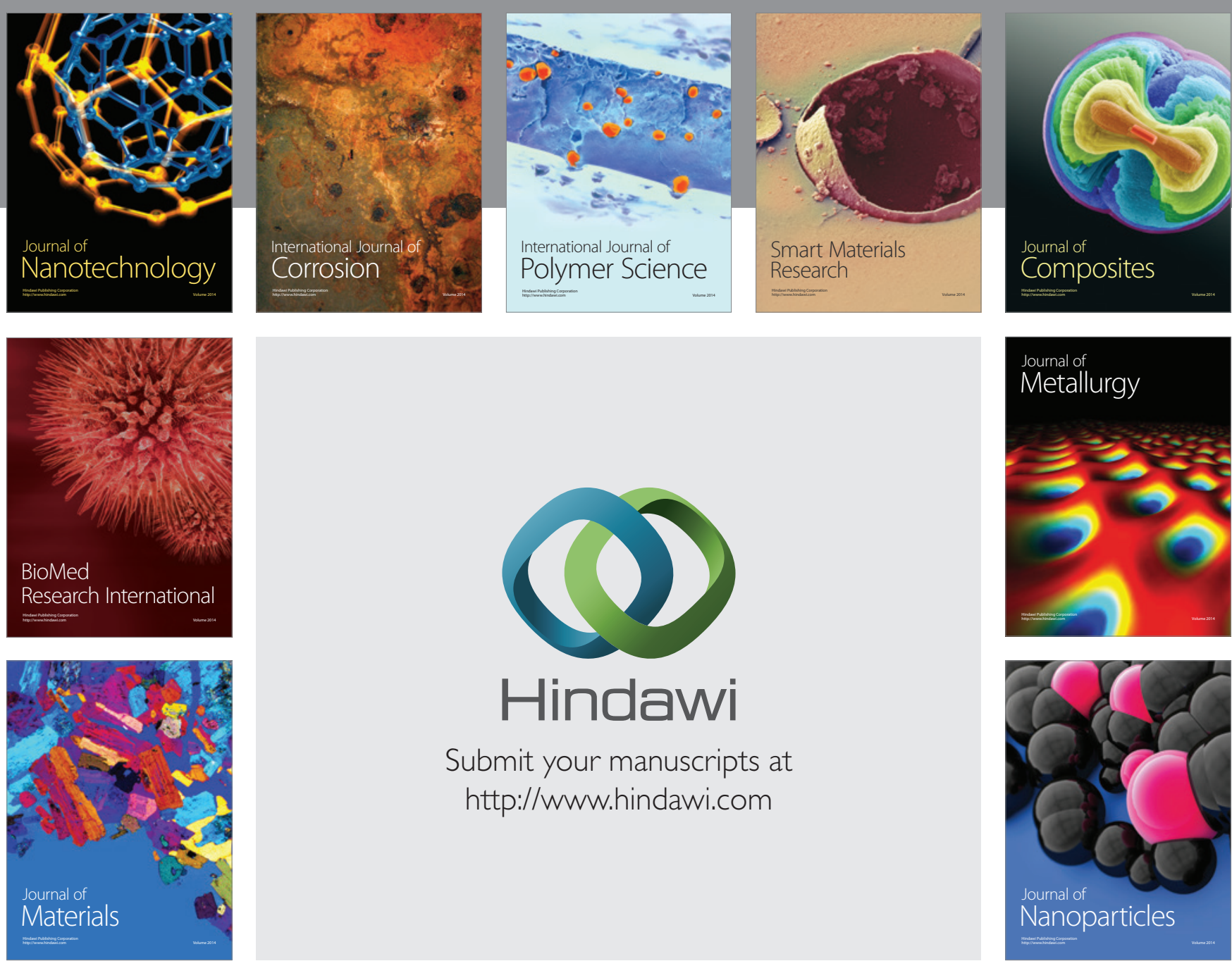

\section{Hindawi}

Submit your manuscripts at

http://www.hindawi.com

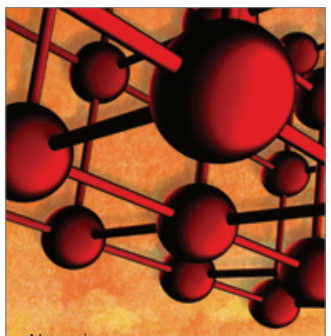

Materials Science and Engineering
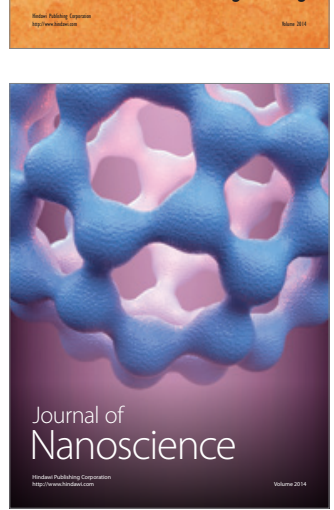
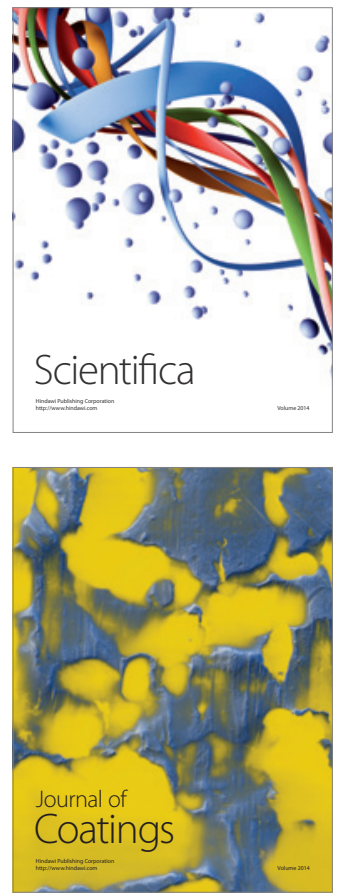
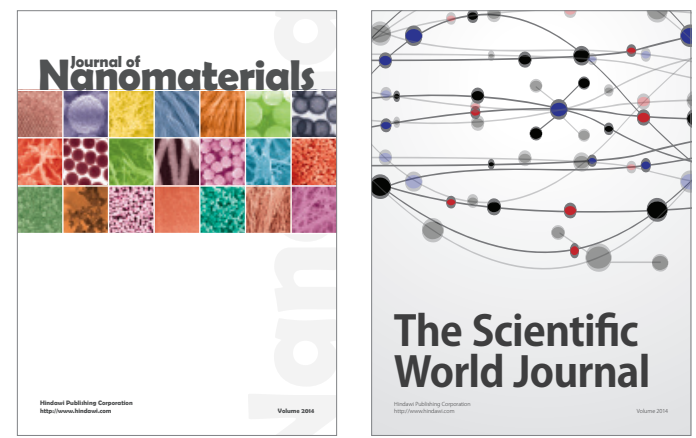

The Scientific World Journal
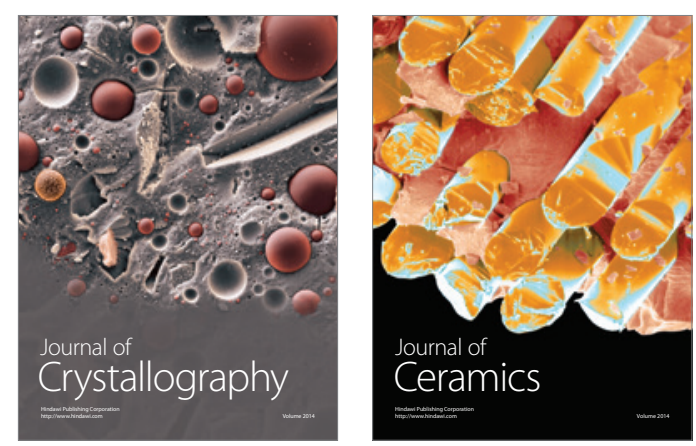
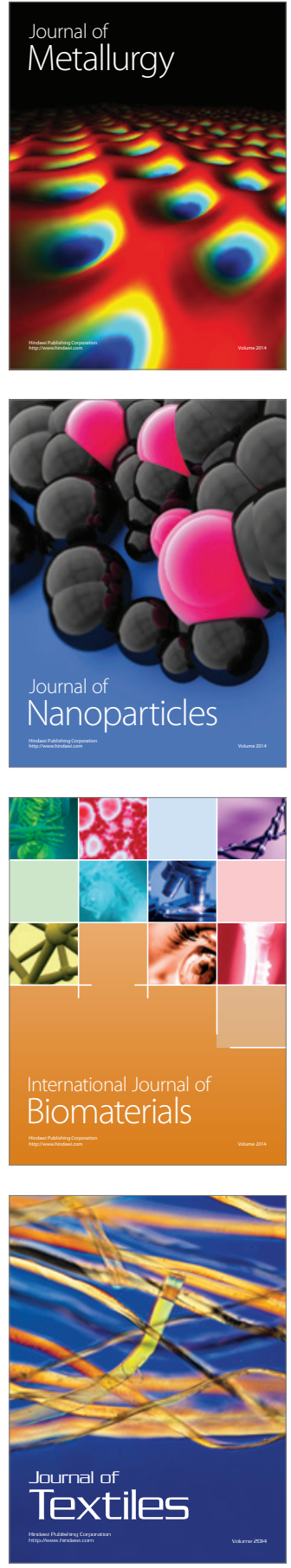